\title{
Rice Blast Management Through Host-Plant Resistance: Retrospect and Prospects
}

\author{
T. R. Sharma $\cdot$ A. K. Rai $\cdot$ S. K. Gupta $\cdot$ \\ J. Vijayan $\cdot$ B. N. Devanna $\cdot$ S. Ray
}

Received: 27 September 2011/ Accepted: 27 November 2011/Published online: 19 January 2012

(C) NAAS (National Academy of Agricultural Sciences) 2012

\begin{abstract}
Rice (Oryza sativa) plays a significant role in achieving global food security. However, it suffers from several biotic and abiotic stresses that seriously affect its production. Rice blast caused by hemibiotropic fungal pathogen Magnaporthe oryzae is one of the most widespread and devastating diseases of rice. The crop rice is vulnerable to this pathogen from seedlings to adult plant stages affecting leaves, nodes, collar, panicles and roots. This disease can be effectively managed through host resistance. Of the 100 blast resistance genes, identified and mapped in different genotypes of rice, 19 genes have been cloned and characterized at the molecular level. Most of these genes belong to nucleotide binding sites and leucine rich repeats. Besides more than 350 quantitative trait loci (QTLs) have also been identified in the rice genome. These blast resistance genes and QTLs have been successfully mobilized in the commercial cultivars by using standard plant breeding techniques and also by marker assisted backcross breeding. With the advent of latest molecular biology techniques and our understanding of the basic mechanisms of Magnaporthe-rice pathosystem, the strategies for broadspectrum resistance to $M$. oryzae can be designed in future.
\end{abstract}

Keywords Magnaporthe oryzae Blast resistance genes $\cdot$ Pi genes $\cdot$ Avirulence gene $\cdot$ NBS-LRR · Pathogen inducible promoter

\section{Introduction}

Rice (Oryza sativa) is one of the major food crops that constitute the staple diet all over the world. It is cultivated everywhere in the world except Antarctica and has tremendous economic importance. More than $23 \%$ of the calories consumed by the world population come from rice. Of the total area under rice cultivation $92 \%$, of the rice is grown in Asia, which is home to more than half of the world population. Rice blast caused by Magnaporthe oryzae poses a serious threat to the world food security as rice is the

T. R. Sharma $(\bowtie)$ - A. K. Rai · S. K. Gupta · J. Vijayan . B. N. Devanna $\cdot$ S. Ray

National Research Centre on Plant Biotechnology, Indian Agricultural Research Institute, IARI, Room No 39, LBS Centre, Pusa Campus, New Delhi 110012, India

e-mail: trsharma@nrcpb.org; trsharma1965@gmail.com staple food for more than $60 \%$ of the world populace. Occurrence of new races of the pathogen in Japan have resulted in frequent breakdown of resistance causing 20 $100 \%$ of crop losses despite utilization of many blast resistance genes in local varieties [62]. In India, blast was first recorded in 1913 and the first devastating epidemic was reported in 1919 in the Tanjore delta of erstwhile Madras state. A 4\% reduction in yield due to blast was estimated for the first time in India. During 1960-1961, the total loss due to blast was 2, 65,000 T [90]. Seven epidemics of blast happened between 1980 and 1987 in the states of Himachal Pradesh, Andhra Pradesh, Tamilnadu and Haryana resulting in huge yield losses. Despite repeated epidemics and huge potential to influence the yields, concrete information on rice yield loss data due to blast disease during the last 30 years is not available. The amount of rice destroyed by blast annually is sufficient to give food to 60 million people world over [98]. Blast is a major contributor to the yield gap 
caused by biotic stresses. Rice production will be required to increase by more than $30 \%$ to meet the staple food requirements by 2030 . In this era of rapidly increasing world population, limitations to increase cultivated land and non-availability of water for irrigation, reducing the loss due to blast can prove to be a critical component towards mitigating the world food security. Despite almost 100 years of dedicated efforts into the study of its genetics, rice blast continues to be the most destructive disease of rice. Therefore, strategies for the reduction of yield losses in an environmentally sustainable and economical manner need to be implemented urgently. In the past decade, focus has been on utilizing resistance genes in rice cultivars rather than using fungicides for the control of rice blast.

The most effective way of management of this pathogen is to use blast resistant cultivars. Hence, there is lot of pressure on rice breeders to develop durably resistant rice cultivars. Resistance genes offer the most lucrative and environmentally safe option for the management of this pathogen. These genes can be utilized in combination of breeding and transgenic programmes to introgress high degree of resistance in otherwise successful and well performing commercial cultivars which are susceptible to $M$. oryzae. The immediate challenge in front of the rice blast community is to build up a repertoire of resistance genes which could be used against continuously evolving and geographically diverse strains of $M$. oryzae. Current status of research on rice blast resistance and their future prospects have been discussed in this article.

\section{Sources of Blast Resistance Genes}

The genus Oryza includes two cultivated and 21 wild species. The Asian rice, $O$. sativa, is cultivated all over the world whereas the African cultivated rice $O$. glaberrima, is grown on a small scale in western Africa. Based on the transferability of genes, two cultivated species, $O$. sativa and $O$. glaberrima, and six wild species, $O$. rufipogon, $O$. nivara, $O$. glumaepatula, $O$. meridionalis, $O$. breviligulata, and $O$. longistaminata have been grouped into a primary gene pool [63]. The Asian rice, O. sativa, is considered to be one of the world's ancient crop species domesticated by human beings dating back to almost 9000 years. The recent study explains that rice was domesticated around 8,20013,500 years ago and rice was first cultivated in the Yangtze Valley of China [81]. Over the period rice plant has encountered many biotic and abiotic stresses which might have influenced its growth and development. During the course of domestication, rice plant has been subjected to selection both by nature and man which led to reduction of diversity in the present rice species. The domesticated rice genotypes which were subjected to mass cultivation occupied major area under rice crop compared to the less cultivated wild rice. Since human beings are growing rice for food purpose, the selection process naturally favoured the agronomically more suitable characters over those of less cultivated species and wild relatives. During long period of cultivation this selection process lead to more uniformity in the cultivated rice lines than wild relatives and land races. The more uniformity in the cultivated rice lines narrowed down the genetic base which indeed favoured plant pathogens for better survival. Meanwhile the large source of genetic pool was left unexplored from wild rice, land races and some cultivated rice germplasm.

Breeders have been successfully tapping available wild sources for many genes in rice breeding for useful traits such as blast resistance genes $P i 9$ from Oryza minuta [116, 2], Pi-40(t) from Oryza australiensis [56] and Pirf2-1(t) from $O$. rufipogon [20]. The wild rice, $O$. rufipogon has been reported to be a potential source for blast resistance genes [103]. The introgression of broad-spectrum blast resistance gene(s) from Oryza rufipogon into indica rice cultivar has also been reported [102].

Even though during the course of rice improvement many genes and their alleles from available land races, cultivars, elite rice lines and wild rice species have been explored, still there is great potential to tap the rice germplasm for the improvement of important traits of rice. So far 100 rice blast resistance $(R)$ genes have been identified (Table 1). Of the 100 blast resistance genes identified, $45 \%$ are from japonica cultivars, and 51\% from Indica cultivars and the rest $4 \%$ from wild species of rice. Contributions of important cultivars having been reported to contain two or more than two blast resistance genes have been compared (Fig. 1). Since only a few such genes have been isolated from wild species of rice, there still remains a lot of unexplored genes among these species which can be a rich source of more useful resistance genes.

\section{Identification and Mapping of Rice Blast Resistance Genes}

Rice blast disease resistance genes were first described in 1923 by Sasaki in Japan. Since the identification of the first rice blast resistance gene Pi-a by Kiyosawa in 1967, from japonica variety Aichi Asahi, around 100 rice blast resistance genes have been identified (Table 1). Different approaches used for the identification and mapping of the rice blast resistance genes are explained briefly in the following paragraph.

\section{Molecular Map Based Approach}

This is the most directed approach for the identification of resistance genes. Availability of complete molecular maps 
Table 1 Blast resistance genes and their genetic location in different rice cultivars

\begin{tabular}{|c|c|c|c|c|c|c|}
\hline \multirow[t]{2}{*}{ S.No. } & \multirow[t]{2}{*}{ Gene name } & \multicolumn{2}{|l|}{ Location } & \multirow[t]{2}{*}{ Source cultivar } & \multirow[t]{2}{*}{ Country } & \multirow[t]{2}{*}{ Reference } \\
\hline & & Chr No. & Position (bp) & & & \\
\hline 1 & Mpiz & 11 & 4073024-16730739 & Zenith $(\mathrm{J})$ & Japan & {$[31]$} \\
\hline 2 & $P b 1$ & 11 & 21711437-21361768 & Modan (I) & Japan & {$[25,40]$} \\
\hline 3 & $P B R$ & 11 & - & St- No 1 (J) & Japan & [26] \\
\hline 4 & $P i(t)$ & 4 & - & P167 (I) & - & [9] \\
\hline 5 & $P i 1$ & 11 & 26498854-28374448 & $\mathrm{LAC} 23(\mathrm{~J})$ & Philippines & [133] \\
\hline 6 & Pilo & 5 & 14521809-18854305 & Tongil (I) & India & [83] \\
\hline 7 & Pill & 8 & - & Zhai-Ya-Quing8 (I) & China & [9] \\
\hline 8 & Pi12 & 12 & $6988220-15120464$ & $\begin{array}{l}\text { K80-R-Hang Jiao-Zhan (J), } \\
\text { Moroberekan (J) }\end{array}$ & Japan & {$[52,137]$} \\
\hline 9 & $\operatorname{Pi13}(t)$ & 6 & $12456009-16303608$ & $\begin{array}{l}\text { O. minuta }(\mathrm{W}), \text { Kasalath }(\mathrm{I}) \text {, } \\
\text { Maowangu }\end{array}$ & Philippines & {$[2,91,95]$} \\
\hline 10 & $\operatorname{Pi14}(t)$ & 2 & $1-6725831$ & Maowangu & Japan & [96] \\
\hline 11 & Pi15 & 9 & $9641358-9685993$ & GA25 (J) & China & {$[92]$} \\
\hline 12 & Pi157 & 12 & 8826555-18050447 & Moroberekan (J) & India & [83] \\
\hline 13 & $\operatorname{Pil6}(t)$ & 2 & $1-6725831$ & Aus373 (I) & Japan & [94] \\
\hline 14 & Pi17 & 7 & $22250443-24995083$ & DJ123 (I) & Philippines & {$[54,93]$} \\
\hline 15 & $\operatorname{Pi18}(t)$ & 11 & 26796917-28376959 & Suweon365 (J) & Korea & {$[142]$} \\
\hline 16 & $\operatorname{Pi19}(t)$ & 12 & $8826555-13417087$ & Aichi Asahi (J) & Japan & [41] \\
\hline 17 & Pi20 & 12 & $6988220-10603823$ & IR24 (I) & Philippines & {$[51]$} \\
\hline 18 & pi21 & 4 & $5242654-5556378$ & Owarihatamochi $(\mathrm{J})$ & Japan & [27] \\
\hline 19 & $\operatorname{Pi22}(t)$ & 6 & $4897048-6023472$ & Suweon365 (J) & Korea & [1] \\
\hline 20 & Pi23 & 5 & 10755867-19175845 & Suweon365 (J) & Korea & [1] \\
\hline 21 & $P i 24(t)$ & 1 & $5242654-5556378$ & Azuenca $(\mathrm{J})$ & France & [107] \\
\hline 22 & Pi25 & 6 & 18080056-19257588 & Gumei 2 (I) & China & {$[141]$} \\
\hline 23 & $\operatorname{Pi25}(t)$ & 2 & $34360810-37725160$ & IR64 (I) & France & [107] \\
\hline 24 & Pi26 & 6 & $8751256-11676579$ & Gumei 2 (I) & China & {$[126]$} \\
\hline 25 & $P i 26(t)$ & 5 & 2069318-2760202 & Azucena (J) & France & [107] \\
\hline 26 & Pi27 & 1 & $5556378-744329$ & Q14 (I) & France & [107] \\
\hline 27 & $P i 27(t)$ & 6 & $6230045-6976491$ & IR64 (I) & France & [107] \\
\hline 28 & $\operatorname{Pi28}(t)$ & 10 & 19565132-22667948 & IR64 (I) & France & [107] \\
\hline 29 & $\operatorname{Pi29}(t)$ & 8 & 9664057-16241105 & IR64 (I) & France & [107] \\
\hline 30 & $\operatorname{Pi3}(t)$ & 6 & - & Pai-kan-tao (J) & Philipines & [78] \\
\hline 31 & $\operatorname{Pi30}(t)$ & 11 & $441392-6578785$ & IR64 (I) & France & [107] \\
\hline 32 & $\operatorname{Pi31}(t)$ & 12 & 7731471-11915469 & IR64 (I) & France & [107] \\
\hline 33 & $\operatorname{Pi32}(t)$ & 12 & 13103039-18867450 & IR64 (I) & France & [107] \\
\hline 34 & Pi33 & 8 & 5915858-6152906 & IR64 (I) & France & [107] \\
\hline 35 & Pi34 & 11 & 19423000-19490000 & Chubu32 (J) & Japan & [135] \\
\hline 36 & $\operatorname{Pi35}(t)$ & 1 & - & Hokkai 188 (J) & Japan & [86] \\
\hline 37 & Pi36 & 8 & $2870061-2884353$ & Q61 (I) & China & [76] \\
\hline 38 & Pi37 & 1 & 33110281-33489931 & St- No 1 (J) & China & {$[12,73]$} \\
\hline 39 & Pi38 & 11 & 19137900-21979485 & Tadukan (I) & India & [34] \\
\hline 40 & $\operatorname{Pi39}(t)$ & 4,12 & - & Chubu 111 (J), Q15 (I) & China & [77] \\
\hline 41 & $\operatorname{Pi40}(t)$ & 6 & $16274830-17531111$ & O. australiensis $(W)$ & Philippines & [56] \\
\hline 42 & Pi41 & 12 & $33110281-34005652$ & 93-11 (I) & China & [129] \\
\hline 43 & $\operatorname{Pi42}(t)$ & 12 & 19565132-22667948 & DHR9 (I) & India & {$[68]$} \\
\hline 44 & Pi44 & 11 & 20549800-26004823 & Moroberekan (J) & USA & [11] \\
\hline 45 & Pi47 & 11 & - & Xiangzi 3150 (I) & China & [48] \\
\hline
\end{tabular}


Table 1 continued

\begin{tabular}{|c|c|c|c|c|c|c|}
\hline \multirow[t]{2}{*}{ S.No. } & \multirow[t]{2}{*}{ Gene name } & \multicolumn{2}{|l|}{ Location } & \multirow[t]{2}{*}{ Source cultivar } & \multirow[t]{2}{*}{ Country } & \multirow[t]{2}{*}{ Reference } \\
\hline & & Chr No. & Position (bp) & & & \\
\hline 46 & Pi48 & 12 & - & Xiangzi 3150 (I) & China & [48] \\
\hline 47 & $\operatorname{Pi5}(t)$ & 9 & - & Moroberekan (J) & Philippines & {$[55]$} \\
\hline 48 & $\operatorname{Pi6}(t)$ & 12 & 4053339-18867450 & Apura (I) & USA & [79] \\
\hline 49 & $\operatorname{Pi62}(t)$ & 12 & 2426648-18050026 & Yashiro-mochi (J) & Japan & {$[127]$} \\
\hline 50 & Pi67 & - & - & Tsuyuake & Philippines & [127] \\
\hline 51 & Pi8 & 6 & $6230045-8751256$ & Kasalath (I) & Japan & {$[91,95]$} \\
\hline 52 & Pi9 & 6 & 10386510-10389466 & O. minuta $(\mathrm{W})$ & China & {$[2,99]$} \\
\hline 53 & Pia & 11 & $4073024-8078510$ & Aichi Asahi (J) & Japan & {$[33,87]$} \\
\hline 54 & $P i b$ & 2 & $35107768-35112900$ & Tohoku IL9 (J) & Japan & {$[125,130]$} \\
\hline 55 & Pib2 & 11 & $26796917-28376959$ & Lemont (J) & Philippines & [119] \\
\hline 56 & $\operatorname{PiCO39}(t)$ & 11 & $6304007-6888870$ & CO39 (I) & USA & {$[10]$} \\
\hline 57 & $\operatorname{Pid}(t) 1$ & 2 & $20143072-22595831$ & Digu (I) & China & [14] \\
\hline 58 & Pid2 & 6 & $17159337-17163868$ & Digu (I) & China & [15] \\
\hline 59 & Pif & 11 & $24695583-28462103$ & Chugoku 31-1 (J) & Japan & [114] \\
\hline 60 & $\operatorname{Pig}(t)$ & 2 & $34346727-35135783$ & Guangchangzhan (I) & China & [139] \\
\hline 61 & PiGD1 & 8 & - & Sanhuangzhan 2 (I) & China & [74] \\
\hline 62 & $P i G D-2$ & 10 & - & Sanhuangzhan 2 (I) & China & {$[74]$} \\
\hline 63 & PiGD3 & 12 & - & Sanhuangzhan 2 (I) & China & [74] \\
\hline 64 & $\operatorname{Pigm}(\mathrm{t})$ & 6 & $10367751-10421545$ & Gumei4 (I) & China & [19] \\
\hline 65 & $P i i$ & 9 & 2291804-28431560 & $\begin{array}{l}\text { Ishikari Shiroke (J), } \\
\text { Fujisaka } 5(\mathrm{~J})\end{array}$ & Japan & {$[53,114]$} \\
\hline 66 & Piil & 6 & 2291804-28431560 & Fujisaka 5 (J) & Japan & {$[91,95]$} \\
\hline 67 & Pii2 & 9 & $1022662-7222779$ & Ishikari Shiroke (J) & Japan & [64] \\
\hline 68 & Piis1 & 11 & 2840211-19029573 & Imochi Shirazu (J) & Japan & {$[30]$} \\
\hline 69 & Piis2 & - & - & Imochi Shirazu (J) & Japan & {$[30]$} \\
\hline 70 & Piis3 & - & - & Imochi Shirazu (J) & - & [30] \\
\hline 71 & $P i k$ & 11 & 27314916-27532928 & Kusabue (I) & China & {$[37,136,124]$} \\
\hline 72 & Pikg & 11 & 27314916-27532928 & GA20 (J) & Japan & [91] \\
\hline 73 & Pikh (Pi54) & 11 & 24761902-24762922 & Tetep (I) & India & {$[111,113]$} \\
\hline 74 & Pikm & 11 & 27314916-27532928 & Tsuyuake (J) & China & {$[60,3]$} \\
\hline 75 & Pikp & 11 & 27314916-27532928 & HR22 (I) & China & [39] \\
\hline 76 & Piks & 11 & 27314916-27532928 & Shin $2(\mathrm{~J})$ & Japan & [23] \\
\hline 77 & Pikurl & 4 & $24611955-33558479$ & Kuroka $(\mathrm{J})$ & Japan & {$[30]$} \\
\hline 78 & Pikur2 & 11 & 2840211-18372685 & Kuroka (J) & Japan & {$[32]$} \\
\hline 79 & Pilm2 & 11 & $13635033-28377565$ & Lemont $(\mathrm{J})$ & USA & [118] \\
\hline 80 & $\operatorname{Pir} 2-3(t)$ & 2 & - & IR64 (I) & Indonesia & [20] \\
\hline 81 & $\operatorname{Pirf2-1}(t)$ & 2 & - & O. rufipogon $(\mathrm{W})$ & Indonesia & {$[20]$} \\
\hline 82 & Pise & 11 & 5740642-16730739 & Sensho $(J)$ & Japan & {$[30]$} \\
\hline 83 & Pise2 & - & - & Sensho $(J)$ & Japan & {$[30]$} \\
\hline 84 & Pise3 & - & - & Sensho $(J)$ & Japan & {$[30]$} \\
\hline 85 & Pish & 1 & $33381385-35283446$ & Shin $2(J)$ & Japan & {$[50]$} \\
\hline 86 & Pish & 11 & $33381385-35283446$ & Nipponbare (J) & Japan & {$[50]$} \\
\hline 87 & Pit & 1 & $2270216-3043185$ & Tjahaja (I), K59 (I) & Japan & {$[39,38]$} \\
\hline 88 & Pita & 12 & $10603772-10609330$ & Tadukan (I), Yashiro-mochi (J) & USA & [7] \\
\hline 89 & Pita2 & 12 & $10078620-13211331$ & Shimokita $(\mathrm{J})$ & Japan & {$[66,82]$} \\
\hline 90 & $\operatorname{Pitp}(t)$ & 1 & 25135400-28667306 & Tetep (I) & India & {$[5]$} \\
\hline
\end{tabular}


Table 1 continued

\begin{tabular}{|c|c|c|c|c|c|c|}
\hline \multirow[t]{2}{*}{ S.No. } & \multirow[t]{2}{*}{ Gene name } & \multicolumn{2}{|l|}{ Location } & \multirow[t]{2}{*}{ Source cultivar } & \multirow[t]{2}{*}{ Country } & \multirow[t]{2}{*}{ Reference } \\
\hline & & Chr No. & Position (bp) & & & \\
\hline 91 & Pitq1 & 6 & 28599181-30327854 & Tequing (I) & USA & [118] \\
\hline 92 & Pitq2 & 2 & - & Teqing (I) & USA & [119] \\
\hline 93 & Pitq3 & 3 & - & Teqing (I) & USA & [119] \\
\hline 94 & Pitq4 & 4 & - & Teqing (I) & USA & [119] \\
\hline 95 & $P i-t q 5$ & 2 & $34614264-35662091$ & Tequing (I) & USA & [118] \\
\hline 96 & Pitq6 & 12 & $5758663-7731471$ & Tequing (I) & USA & [118] \\
\hline 97 & $\operatorname{Piyl}(t)$ & 2 & - & Yanxian No 1 (I) & China & {$[71]$} \\
\hline 98 & $\operatorname{Piy2}(t)$ & 2 & - & Yanxian No 1 (I) & China & [71] \\
\hline 99 & $\mathrm{Piz}$ & 6 & 10155975-10517612 & $\begin{array}{l}\text { Zenith }(\mathrm{J}) \text {, Fukunishiki (J), } \\
\text { Toride } 1(\mathrm{~J}) \text {, Tadukan (I) }\end{array}$ & Japan & {$[31,138]$} \\
\hline 100 & $P i z h$ & 8 & 4372113-21012219 & Zhai-Ya-Quing8 (I) & China & [9] \\
\hline
\end{tabular}

$J$ japonica; $I$ indica; - not known

Fig. 1 Cultivar-wise distribution of blast resistance genes identified in rice. Rice Cultivars which have been reported to contain more than two blast resistance genes have been compared. I and $\mathbf{J}$ given in parenthesis indicate that the cultivar belongs to either indica or japonica type of rice

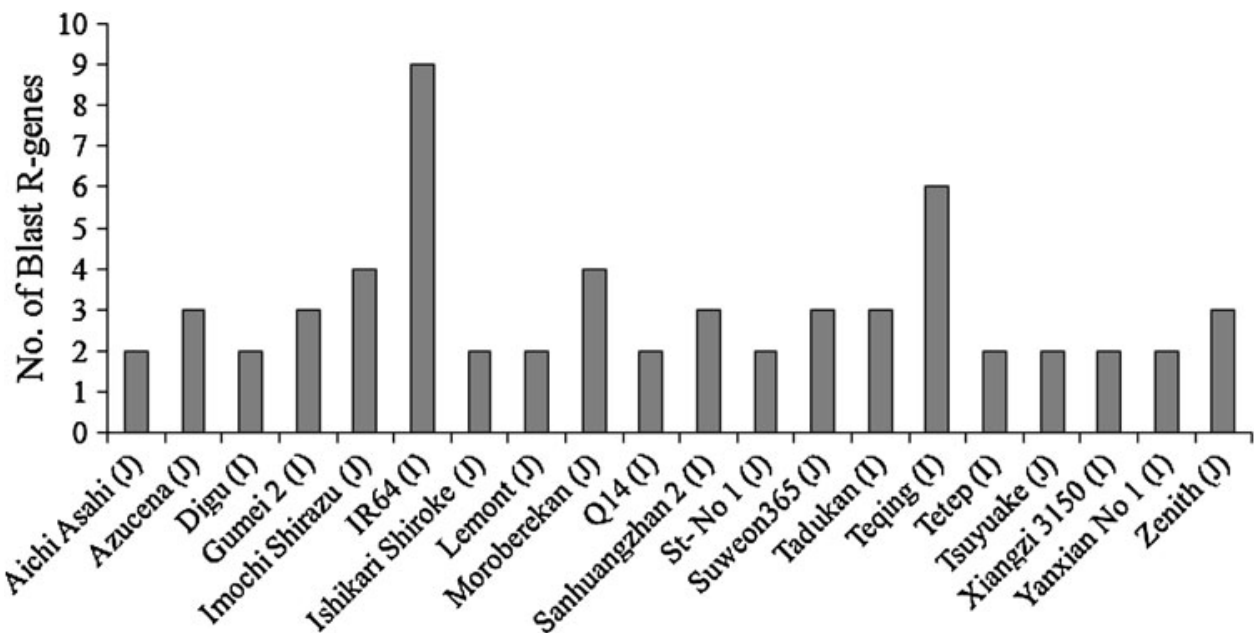

of all the chromosomes of rice helps in utilizing available marker information for the identification and localization of the resistance genes. This strategy has been used for identification of 30 blast resistance genes like Pit, Pi27(t), Pish, Pidl(t), Pig(t), Piy(t), Piy2(t), Pi39(t), Pi10, Pi40(t), Piz, Pigm(t), Pi33, Pi5(t), Pi15, PiCO39(t), Pi38, PBR, Pbl, Pi-k ${ }^{h}$, Pil, Pik-m, Pik, Pik-p, Pik-s, Pi62(t), Pi157, Pita-2, Pi39(t), and Pi2O(t). Identification and cloning of blast resistance genes in India began in 2002 when rice line Tetep was found to be highly resistant for most of the strains of M. oryzae [109]. Since then, four blast resistance genes have been identified in India. Owing to the huge potential of Tetep in resistance breeding for the effective management of rice blast in the North-Western region of India, the $P i-k^{h}$ (Pi54) gene was mapped in the same cultivar Tetep using different types of DNA markers [111]. Earlier, blast resistance gene Pitp $(\mathrm{t})$ has been mapped in cultivar Tetep by using simple sequence length polymorphism markers [5]. Besides, Pi38 was identified in indica rice Tadukan [34] and $P i-42(t)$ from a indica cultivar DHR9 by Kumar et al. [68]. Because of its effectiveness against many strains of $M$. oryzae and availability of closely linked and also gene based markers, the $P i-k^{h}$ (Pi54) gene is now being introgressed in Indian cultivars of rice using marker assisted back cross breeding [115].

\section{The In Silico Approach}

This approach uses computational methods for identification of the suitable candidate genes. Here the available sequence of two or more genomes are used for genome wide comparison [108]. Candidate genes are identified in silico by gene prediction programs like, FGENESH and RiceGAAS using rice genome sequence of the prescribed size of fragment. For the verification of the true candidate, PCR based markers are developed and used as co- 
segregation markers to screen blast resistant and susceptible varieties. Shang et al. [108] identified blast resistance gene Pid3 by genome-wide comparison of paired NBSLRR genes and their pseudogene/alleles between the genome sequence of indica rice cultivar 93-11 and japonica line Nipponbare available in the public domain.

\section{QTL Mapping Approach}

Quantitative traits are the traits that are regulated by multiple genes in a cumulative effect for yield, drought tolerance and disease resistance. The genomic locations of the genes required for these traits are known as quantitative trait loci (QTL). Basically there are three approaches for QTL mapping such as single marker analysis (SMA), standard interval mapping (SIM) and composite interval mapping (CIM). Typical single-marker-analysis method divides the mapping population into classes based on the genotype at each marker locus, and demarcates declares a QTL if there is a significant difference in the mean phenotypic score for each of the groups. This method has been employed for the first time for the identification of QTL for rice blast resistance in $\mathrm{cv}$. Moroberekan, a japonica rice cultivar cultivated in Africa [123]. The SIM uses the flanking molecular markers of a locus and maps the QTL between two marker intervals. This method is more precise in locating QTL than SMA. The major problem with SIM is that linked and unlinked QTLs affect the result of the analysis and may result in identification of false QTLs. The method was used for QTL analysis and mapping of blast resistance gene pi21 in Japanese upland rice cv. Owarihatamochi [27]. The composite interval mapping uses the subset of markers at linked as well as unlinked QTLs. It helps in the detection of QTL interaction and also information from these markers increases the power of QTL detection. Using above mentioned three methods 350 QTLs for blast resistance have so far been identified [4]. Besides, 23 blast resistance loci such as Pi24(t), Pi35(t), Pitq5, Pi25(t), pi21, Pi26(t), Pi27(t), Pi25(t), Pitq1, Pizh, Pi29(t), PiGD-1(t), Pi28(t), PiGD-2(t), Pilm2, Pi30(t), Pi7(t), Pi34, Pi24(t), Pitq6, Pi31(t), Pi32(t), PiGD-3(t) have also been identified within these QTL regions (Table 1).

\section{Molecular Cloning of Blast Resistance Genes}

Once genes are fine mapped with closely linked DNA markers, map based cloning approach can be effectively used for molecular cloning and characterization of blast resistance genes in rice. Although, 100 blast resistance genes have been identified and mapped both in indica and

Table 2 List of cloned and characterized blast resistance genes in rice

\begin{tabular}{|c|c|c|c|c|c|}
\hline S.No. & $\begin{array}{l}\text { Gene } \\
\text { designation }\end{array}$ & $\begin{array}{l}\text { Chromosome } \\
\text { No. }\end{array}$ & Marker & Cloning strategy & $\begin{array}{l}\text { Domain } \\
\text { combination }\end{array}$ \\
\hline 1 & $P i b$ & 2 & $\begin{array}{l}\text { Os02g57310, b213, b28, b2, b3989, } \\
\text { RM208, S1916, G7031 }\end{array}$ & MB & NBS-LRR \\
\hline 2 & Pita & 12 & $\begin{array}{l}\text { Os12g18360, SP4B9, SP9F3, ta642, ta801, } \\
\text { ta3, ta577, Pi-ta 440, Pi-ta 1042, Pi-ta } 403\end{array}$ & MB & NBS-LRR \\
\hline 3 & Pi54 (Pi-kh) & 11 & TRS26, TRS33, RM206 & MB & NBS-LRR \\
\hline 4 & Pid-2 & 6 & CAPS1, CAPS 8, Os06g29810 & MB & Lectin receptor \\
\hline 5 & $\operatorname{Pi9}$ & 6 & Os06g 17900 & $\mathrm{MB}$ & NBS-LRR \\
\hline 6 & $P i-2$ & 6 & Z4792 & MB & NBS-LRR \\
\hline 7 & $P i z-t$ & 6 & Z4792 & MB & NBS-LRR \\
\hline 8 & Pi36 & 8 & Os08g05440, CRG3 & MB & CC-NBS-LRR \\
\hline 9 & Pi37 & 1 & RM543, FPSM1, RM302, RM212 & MB In Silico & NBS-LRR \\
\hline 10 & Pikm & 11 & K2167, K4731, K6441, 85H07554, k3952 & MB & NBS-LRR \\
\hline 11 & $P i 5$ & 9 & JJ113-T3, JJ817 & MB & CC-NBS-LRR \\
\hline 12 & Pit & 1 & $\mathrm{t} 311, \mathrm{t} 256, \mathrm{t} 8042$ & MB & CC-NBS-LRR \\
\hline 13 & Pid3 & 6 & - & In Silico homology based & NBS-LRR \\
\hline 14 & pi21 & 4 & RM16913, RM1359 & MB & NBS-LRR \\
\hline 15 & $P i s-h$ & 1 & - & Mutant Screening & CC-NBS-LRR \\
\hline 16 & $\mathrm{Pbl}$ & 11 & RM206, S723-Pb3810 & MB & CC-NBS-LRR \\
\hline 17 & $P i-k$ & 11 & RM5766, K33, 34, 28 & MB & CC-NBS-LRR \\
\hline 18 & $P i k-p$ & 11 & $\mathrm{~K} 37-\mathrm{K} 22$ & MB In silico & CC-NBS-LRR \\
\hline 19 & Pia & 11 & - & Multifaceted genomics approach & CC-NBS-LRR \\
\hline
\end{tabular}

- Not known; $M B$ map based 


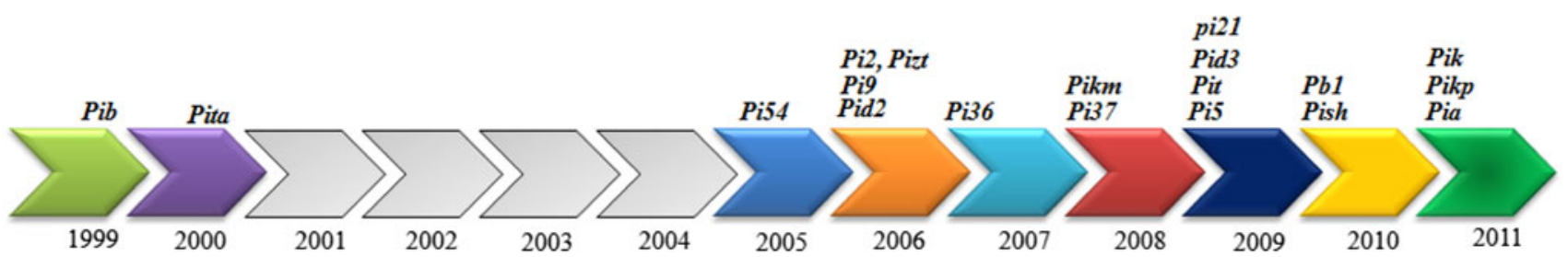

Fig. 2 Time line in the cloning of blast resistance genes in rice. Each block represents a year. Name of the cloned genes is given on the top of each block

japonica types of rice, only 19 genes have been cloned (Table 2).Cloning of resistance genes is an important first step towards understanding R-gene structure and its function, which is of prime importance in understanding the basis of disease resistance. The first breakthrough in cloning blast resistance gene came almost 90 years after the start of blast genetics study, when Pib was cloned in Japan in 1999 [125]. Pita, another important gene for blast resistance was cloned in 2000 in USA [7]. After a gap of 5 years, $P i-k^{h}$ (Pi54) was cloned in India from an indica $\mathrm{cv}$. Tetep [113]. Structural organization analysis of the $100 \mathrm{~kb}$ region around $P i-k^{h}$ locus in both indica and japonica rice genotypes found variation in number and distribution of motifs involved in phosphorylation which results in the resistance phenotype in Tetep [69]. The $P i-k^{h}$ gene from Tetep was re-designated as Pi54 after the gene was further relocated to a slightly distant position from $P i-k h$ locus [112]. Through complementation test, the Pi54 gene was found to confer resistance to four different isolates of the blast fungus in transgenic lines TP-Pi54-2 and TP-Pi54-15, among others. The gene was found to induce the synthesis of callose ( $\beta-1,3$ glucan) in response to pathogen challenge, indicating its possible role in the initiation of a defense response cascade in the blast resistant plants [100]. The microarray and enzymatic analyses showed that $\mathrm{Pi} 54$ gene activates a cascade of defense response genes in a transgenic line up to T6 generation [35]. After sequencing of the rice genome, more and more blast resistance genes are being cloned by different groups. Within a span of 12 years, 19 blast resistance genes have already been cloned (Fig. 2). A maximum of four genes namely Pid2, Pi9, Pi2 and Piz- $t$ and Pi5, Pit, Pid 3 and pi21 were cloned, each in 2006 and 2009, respectively (Table 2).

Though R-genes like sequences are distributed throughout the rice genome, chromosome 11 has been reported to contain maximum number of resistance genes [104]. Genetic and molecular analysis has revealed that out of 100 blast resistance genes identified and mapped, nearly half of these are localized on chromosomes 11, 12 and 6 (Fig. 3). About $24 \%$ of the mapped genes are located on chromosome 11 followed by 15 and $14 \%$ of the genes mapped on chromosomes 12 and 6 , respectively.

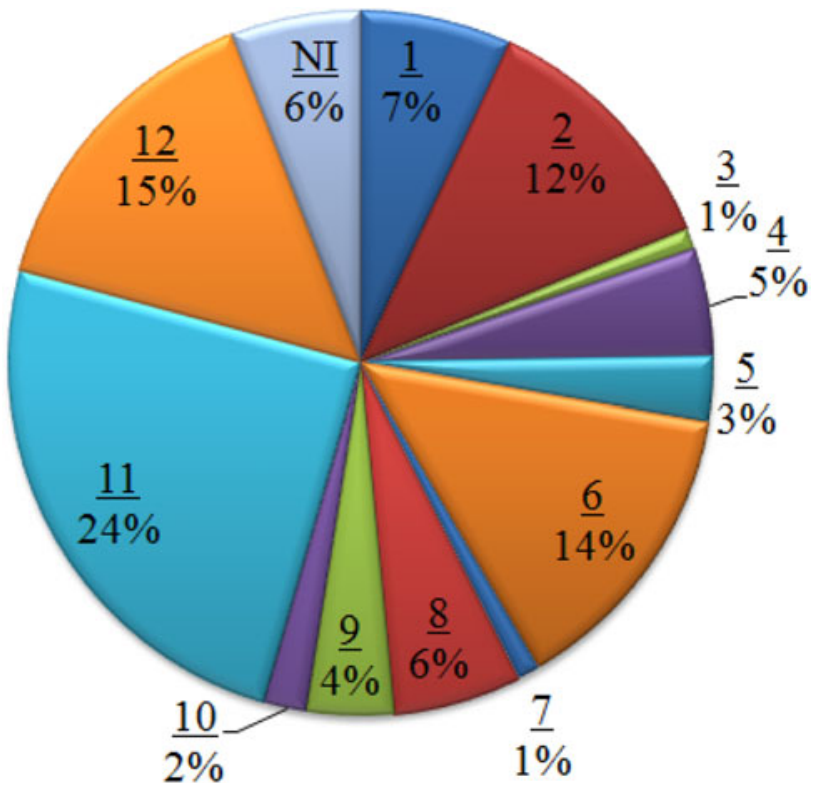

Fig. 3 Chromosome-wise distribution of blast resistance genes in rice. Chromosome number has been underlined. NI no information about the chromosome

All the R- genes cloned till date have been divided into five classes based on their predicted protein structure [36]. The largest class of R-genes encodes nucleotide bindingleucine rich repeats (NBS-LRR) protein. The function of the central NBS domain is concerned with ATP binding and/ or hydrolysis, and the C-terminal LRR participates in protein-protein interactions of $R$ - and $A v r$-genes [120]. The NBS-LRR proteins are sub-classified into Toll/interleukin1 receptor (TIR) and coiled-coil (CC) groups on the basis of their N-terminal sequence [132]. NBS-LRR genes are clustered in the genomes [80] and sequences of many clusters are highly homologous to one another. It is believed that the individual genes have evolved through a process of duplication of these conserved regions [80]. Out of 19 cloned and characterized proteins of blast resistance genes, ten proteins belong to the NBS-LRR type while eight proteins are of CC-NBS-LRR class. The Pid-2 protein is a unique type of B-lectin receptor having serine threonine kinase type 


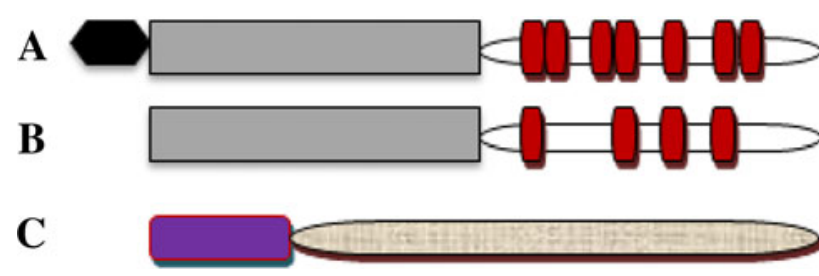

Fig. 4 Different types of domain combinations present in proteins of cloned blast resistance genes. (a) CC-NBS-LRR class contain a CC domain (black hexagon) in addition to NBS (grey rectangle) and LRR (red circles), (b) NBS-LRR class, (c) Serine threonine kinase (purple rectangle is the B-lectin domain while brown one represents kinase domain)

domain. Typical protein structures of three types of these rice blast resistance genes are shown in Fig. 4.

\section{Allele Mining for Rice Blast Resistance Genes}

Plant breeding for superior agronomic traits largely depends on the amount of variation found in the plant germplasm. Like all living organisms, plants did accumulate many useful alleles for various agronomic characters. The natural mutation is a great contributor for evolution of new alleles. Mutations like transitions, transvertions and InDels are the basis for this evolution. Though during the course of evolution, plant breeders have tapped many useful alleles, still there is a huge potential for gainful exploration of many other useful alleles. The process of identification of alleles of the gene responsible for a given trait and their variants in other genotypes is known as allele mining. Different approaches used for allele mining are briefly explained in the following paragraph.

Tilling (targeting induced local lesions in genomes) is a molecular biology technique that helps in direct identification of induced point mutations in the gene by heteroduplex analysis [122]. In this technique artificially induced mutations are subjected to phenotypic and genotypic analysis. The application of above approach to look for natural mutations in germplasm is called EcoTILLING [16]. Both techniques use mismatches produced by heteroduplexes of alleles of a gene. These sites are subjected to single strand nuclease treatment of end labeled heteroduplexes. The fragments produced in above treatment are separated and site of mutation can be identified by fragment size analysis. Besides, sequence and sequencingbased allele mining approach uses PCR based amplification of the alleles of a gene in different genotypes followed by sequencing of those alleles. Then the sequences are analyzed for the presence of SNPs, and InDels which are used to construct haplotypes, to understand the effect of mutations on gene structure and organization.
These above mentioned approaches were used to identify alleles of important blast resistance genes from wild rice species like $P i$-ta+ from $O$. rufipogon (Griff) [28] and from $O$. rufipogon (ETOR) [128], Pi-rh from $O$. rhizomatis (Das 2008), Pi-ta from O. rufipogon [47] and Pid3 from 36 accessions of wild rice $O$. rufipogon [108]. In the latter two examples, Huang et al. [47] and Shang et al. [108] used PCR based approach to amplify and sequence alleles of 36 accessions of wild rice. Allele mining is also reported in many cultivated rice plants. Kiyosawa and his colleagues identified 14 resistance alleles at eight loci: $P i-a, P i-i, P i-k$ (alleles: $P i-k, P i-k^{s}, P i-k^{m}, P i-k^{h}$ and $\left.P i-k^{P}\right), P i-z\{P i-z$ and $\left.P i-z^{t}\right), P i-t a\left\{P i-t a\right.$ and $\left.P i-t a^{2}\right), P i-b, P i-t$ and $P i-s^{h}$ [65], $P i-$ 2(t) $\left\{P i-z, P i z-5, P i-z^{t}, P i-9(t)\right\}, P i-4\left\{P i-4^{a}(t), P i-4^{b}(t), P i-\right.$ ta\}, Pi-5(t) $\{P i-3(t), P i-i(t)\}, P i-14(t)\{P i-16(t), P i-d(t)\}$, $P i-k P i-k^{m}, P i-k^{s}$ or 5, Pi-k $\left., P i-k^{p}, P i-k^{h}\right\}, P i-t a\left\{P i-t a^{2}\right\}$, $P i-b\{P i-s\}$ [58]. Sharma et al. [110] reported allele mining for important blast resistance genes like, $P i-t a, P i-k^{h}$ and $P i-z(t)$ in Indian land races of rice. They found that $P i-k^{h}$ and $P i-z(t)$ alleles are more variable than Pi-ta alleles. Similarly, allele mining for blast resistance gene $P i-k^{h}$ (Pi54) in seven wild species and five land races of rice has been reported [101]. Still application of these novel alleles in rice improvement programmes is yet to be exploited by the plant breeders and molecular biologists.

\section{Introgression of Blast Resistance Genes in Commercial Cultivars}

Since the beginning of agriculture, plant breeding has been considered as the most popular method for crop improvement. To develop crop plants for higher yield and other qualitative traits, it has been the method used from time immemorial. Selection of plant varieties for biotic and abiotic stresses is a major objective of plant breeding. Traditionally, breeding techniques like pure line selection, mass selection, recurrent selection and backcross selection have been followed for breeding crops for stress resistance. Bordeos et al. [2] used backcross breeding followed by embryo rescue approach to transfer bacterial blight and blast resistance genes from the tetraploid wild rice Oryza minuta to cultivated rice, O. sativa cv. IR31917-45-3-2. Some genes have also been introgressed directly from the wild rice [102]. A detailed review on the current status of rice blast resistance is also available [62].

The advent of molecular biology tools has led to the emergence of new methods like marker assisted selection (MAS) which can facilitate gene pyramiding in plants. Gene pyramiding is a strategy which uses either traditional breeding methods or modern molecular biology approaches to introgress more than one gene for specific trait into single genetic background. Deployment of single dominant gene is 
a common method to breed crop plants for biotic and abiotic stress resistance. The deployment of single gene for biotic stress is generally subjected to breakdown of resistance as biotic agents always try to overcome plant defense mechanisms. Availability of various molecular markers like simple sequence repeat (SSR), restriction fragment length polymorphisms (RFLP) and single nucleotide polymorphism (SNP) etc. have fastened the procedure for gene introgression and gene pyramiding. The R-genes like Pil, Pi5, Piz-5 and Pita [43, 70, 75, 84] have been introgressed in various elite rice genotypes using MAS.

Gene pyramiding helps in the development of broad spectrum, durable resistance to rice blast. The approaches need careful characterization of the resistance spectrum of the genes to be used and combining them in an effective 'pyramid' against the target pathogen population [134]. Hittalmani et al. [43] used closely linked RFLPs and polymerase chain reaction (PCR)-based markers to put three blast resistance genes Pil, Piz-5 and Pita into a susceptible cultivar CO39. They found that the plants carrying the two- and three-gene combinations including Piz-5 showed enhanced resistance to blast compared to the plants with Piz-5 alone. Recently, Koide et al. [67] developed pyramided genotypes of Pish and $P i b$ in genetic background of CO39. Singh et al. [115] developed improved Pusa 6A, Pusa 6B and PRR78, the parental genotypes of rice hybrid Pusa RH 10 by transferring Pi54 + Piz5 genes for blast resistance. Pyramiding of resistance genes for more than two pathogens is of great significa for plant breeding. This approach was used to pyramid three major R-genes $\mathrm{Pi}-1, \mathrm{Piz}-5$ and $\mathrm{Xa} 21$ into rice using MAS and genetic transformation and the two-gene pyramids showed more enhanced resistance than the parental genotypes [85]. Three genes such as $P i-d(t) 1, P i-b$, and $P i-t a^{2}$ have been stacked into a promising donor line of rice, G46B [13] and two genes Pil and Pi2 into cv. Zhenshan 97 [42]. These findings show that the pyramiding of rice blast resistance genes alone or in combination with other disease resistance genes will be of great significance in preventing huge losses being incurred by ever evolving $M$. oryzae pathogen.

\section{Future Prospects}

Pathogen-Responsive Promoters of Rice Blast

Resistance Genes

Even though it is possible to reduce the crop losses to some extent through the deployment of R-genes, durable resistance in most crops still remains an elusive dream. The question therefore is, what is to be done now that can lead to a significant step towards the desired goal of minimizing the crop losses due to biotic stresses. In fact, considerable effort has been directed for the development of durable resistance by gene pyramiding. However, pyramiding of several $\mathrm{R}$ genes with constitutive promoter by transgenic approach has problems associated with it such as the imposition of a fitness cost to the plant [121]. The ectopic expression of Rgenes may also sometimes activate defence response pathway in the absence of pathogen, which is likely to reduce crop yield [88]. This implies that the use of a pathogenresponsive promoter instead of a constitutive promoter would be a smarter option for deployment of R-genes. The identification of pathogen-responsive promoters would also be crucial in testing the $R-A v r$ two-component system for engineering resistance against rice blast disease.

\section{Cloning and Use of Pathogen-Responsive Promoters}

A number of pathogen-responsive promoters have been identified in different plant species during the past few years but only few have been well characterized. Ideally, a promoter that is desirable for use as a tool to enhance plant resistance should be exclusively induced by the pathogen in question and also in those tissues and developmental stages which are most amenable to infection by the pathogen. However, it would be difficult to identify such a promoter since plant promoters are comprised of modular elements each of which may have specific or overlapping functions. Indeed, a large number of genes whose promoters have been characterized and shown to be responsive to pathogens are also induced by other stresses [21, 45, 46, 59, 97]. However, advances in the understanding of natural pathogen-responsive promoters and their specific cis-elements would help us to explore the possibilities of allowing their modification to suit our interests and also in the development of synthetic promoters which may be a promising tool to achieve plant resistance [106]. Most of the earlier work on the identification of pathogen-responsive cis-acting elements in plants has already been reviewed by Rushton and Somssich [105].

It has been a daunting task to identify promoters that are specifically induced by pathogens alone and not by extraneous signals possibly due to the crosstalk between biotic and abiotic stress pathways. The identification of exclusively pathogen responsive promoter would indeed be a boon to researchers involved in engineering disease resistance. In rice, the OsPRIOa promoter was found to be induced by the pathogen Xanthomonas oryzae pv. oryzae and also by salicylic acid, jasmonic acid, ethephon, abscisic acid and $\mathrm{NaCl}$ [49]. A W-box like element WLE1 present between -687 and -637 bp was found to be crucial for salicylic acid response. Another promoter that is responsive to the $X$. oryzae pv. oryzae is of the OsWRKY13 gene which harbours two cis-elements PRE2 and PRE4 which are believed to negatively regulate gene expression in healthy plants. Under pathogen-challenged conditions, these two 
elements positively influence gene expression most probably by binding of specific proteins [8]. So far, pathogenresponsive promoters identified in response to the blast pathogen M. oryzae have been few and not that well characterized. The rice $L T P 1$ gene was found to be upregulated 1 or 2 days following inoculation with $M$. oryzae in two rice cultivars exhibiting compatible and incompatible hostpathogen interactions. It was found that the induction was mainly restricted to the site of infection and also induced by wounding. However, although the promoter contained the TCA element that had been previously found in many genes induced by wounding or pathogen attack [29], the role of this element in the LTP1 promoter has not been functionally validated. The rice phenylalanine ammonia lyase transcript $r P A L-5$ was induced as early as $1 \mathrm{~h}$ post treatment with $M$. oryzae and its derived elicitor. Previously the same gene has also found to be induced at different developmental stages as well as by wounding, TMV infection and treatment with fungal elicitors [140]. The rice thaumatin-like protein (Rtlp1) has also been induced rapidly by $M$. oryzae apart from treatment with salicylic acid, methyl jasmonate and wounding. A $120 \mathrm{bp}$ region of the promoter of rice thaumatin-like protein gene consisting of six $\mathrm{W}$-boxes plays a major role in activating expression in elicitor-treated cells of rice. However, in all the blast pathogen-responsive genes discussed above, the role of individual cis-elements in gene expression has not been investigated. These promoters, however, have a broader application and could be useful in engineering resistance to chewing insects and larvae as well that also cause a lot of yield loss in rice. A promoter responsive exclusively to the rice blast pathogen would require that the motifs responsive to the pathogen and wounding be separate, which may complicate the process of promoter identification itself as the blast pathogen itself causes wounding during appressorium penetration of host tissues. The identification of early induced transcription factors such as OsWRKY13, antifungal proteins, phytoalexins and potent R-genes etc. have given hope for development of novel strategies to achieve immunity against the rice blast pathogen. Simultaneous identification of strong and selective promoters that lead to expression in the infected tissues instead of constitutive expression is the next step for the effective utilization of previous efforts. The discovery of such novel pathogen-responsive promoters that are activated early in the signal transduction pathway in rice would be greatly helpful in reducing yield losses.

Application of Avirulence Genes in Rice Blast

Resistance

Avirulence (Avr) genes are the genes that encode molecules which function during normal growth and pathogenicity of the pathogen. Most likely this activity is quite distinct from the role of the $A v r$-gene product in triggering $R$-gene mediated resistance in the host plant. Avr genes most probably have distinct and specific function to aid the pathogen in the process of infection but the resistant host plants have learned the way to detect them as foreign elements by employing specific $R$-genes which they have derived during the process of co-evolution and use them as a weapon against its enemy [57]. In plants, resistance to a particular pathogen is governed by incompatible interaction which follow gene-for-gene hypothesis [24]. So, the Avr genes specify the host range of the pathogens, by determining whether a pathogen carrying a set of Avr genes would be capable of producing disease on a particular host which contains complementary $R$-genes or not. Host range shift of the pathogen can also be achieved by the modification or shedding of avirulence genes and this phenomenon is quite common in the natural populations of $M$. oryzae.

Till date, 11 avirulence genes have been cloned and characterized in M. oryzae. Of these eight have been cloned by map based cloning approach and rest three by genome wide avirulence gene search followed by association mapping. The first cloned Avr gene of M. oryzae was $P W L$ gene family consisting of four genes, viz., $P W L 1, P W L 3$, $P W L 4$ [61] and $P W L 2$ [117]. These are present as a rapidly evolving gene family of small, glycine rich hydrophilic secreted proteins. Another Avr gene, Avrl-Co39 [22], has also been found to confer resistance against rice blast disease but its protein product is not well characterized. $A v r$-Pi-ta [89], the most well-studied Avr gene of M. ory$z a e$ which is avirulent on resistance gene $P i$-ta, has been cloned by using map based cloning method and encodes a secreted metalloprotease expressed during infection and colonization of rice. The ACE- 1 avirulence gene [6] is unusual in that it encodes a polyketide synthase/non-ribosomal peptide synthetase (PKS/NRPS) fusion protein which is considered to be an enzyme, named, avirulence conferring enzyme-1 (ACE-1). It is a large protein of 4,035 amino acids and unlike the other Avr- proteins found in $M$. oryzae but not secreted out of the cell. Rather it produces toxic metabolite which aid in the aggressiveness of the fungus. Resistance to $M$. oryzae isolates containing active $A C E-1$ gene is governed by resistance gene Pi33. AvrPiz-t, the latest one to be cloned by map based cloning approach is predicted to produce a secreted protein that triggers immunity in rice mediated by the blast resistance gene Piz$t$ [72]. With the availability of the whole genome sequence of M. oryzae (strain 70-15) in the public domain [18] and the advent of high throughput sequencing techniques, genome wide avirulence gene searching followed by association genetic studies have come up as an alternate approach to clone avirulence gene from M. oryzae. 
Table 3 Important features of the $A v r$ genes cloned from $M$. oryzae

\begin{tabular}{lclll}
\hline Name & $\begin{array}{l}\text { Protein } \\
\text { length (aa) }\end{array}$ & Function & NCBI accession no. & Reference \\
\hline$P W L 1$ & 147 & & $\mathrm{U} 36923$ & {$[61]$} \\
$P W L 2$ & 145 & Small glycine rich hydrophillic & $\mathrm{U} 26313$ & {$[117]$} \\
$P W L 3$ & 137 & secreted protein & $\mathrm{U} 36995$ & {$[61]$} \\
$P W L 4$ & 138 & & $\mathrm{U} 36996$ & {$[61]$} \\
Avrl Co39 & 45 & Hypothetical protein & AF463528 & {$[22]$} \\
Avr Pi-ta & 223 & Secreted metelloprotease & AF207841 & {$[89]$} \\
ACE1 & 4034 & Polyketide synthase/non-ribosomal & AJ704622 & {$[6]$} \\
& & peptide synthase fusion protein & & {$[72]$} \\
AvrPiz-t & 108 & Predicted secreted protein capable & EU837058 & \\
Avr-Pia & 85 & to suppress programmed cell death & & AB498873 \\
Avr-Pii & 70 & Hypothetical protein & AB498874 & {$[131]$} \\
Avr-Pik/km/kp & 113 & & AB498875 & {$[131]$} \\
\hline
\end{tabular}

Following such strategy, three new avirulence genes, AvrPia, Avr-Pii and Avr-Pik/km/kp, have recently been discovered and cloned simultaneously [131] but their functions have not been characterized as yet. Few of the general information about the eleven avirulence genes cloned till date from M. oryzae or M. grisea is given in Table 3.

In our laboratory, an avirulence gene, AvrPi54, has been identified and cloned from an isolate of $M$. oryzae which is avirulent on rice genotypes containing resistance gene Pi54. We have used the whole genome sequence of M. oryzae strain 70-15 available in the public domain. A total of 474 candidate $A v r$-genes has been identified in the $37.878 \mathrm{Mb}$ genome of $M$. oryzae strain 70-15. Of these 25 candidates were used for in silico protein modeling and performing protein-protein interaction with blast resistance gene Pi54. The study has revealed two candidate genes, AvrPi54-1 and AvrPi54-2 which have the potential of being the true candidate as the protein model of these two docked on the protein model of Pi54 protein in silico annotation studies also showed that these two Avr genes hold the potential of being the perfect counterparts of blast resistance gene Pi54.

\section{$R-A v r$ Two Component System: Designing Broad Spectrum Blast Resistance}

Evidently, a specific $R$ gene gives protection against one pathogenic strain containing its cognate $A v r$ gene. It seems to be a good ploy to stack number of $R$ genes in a plant genome which will provide protection against a number of pathogen. This is, in fact, the strategy in practice which is commonly known as gene pyramiding. In a gene pyramided plant every $R$ gene product will recognize its counterpart Avr gene product individually and lead to a common signaling pathway of hypersensitive response (HR) that will ultimately lead to a broad spectrum disease response.

However, as discussed earlier, simply pyramiding of several $R$ genes has some problems associated with it. As, introducing many $R$ genes in a single plant may sometime have some negative effects on the plants, it may be better to deal with a single $R$-gene rather than stacking number of $R$-genes within a single plant genome. Standing up to this challenge De Wit gave the concept of $R-A v r$ two component systems [17]. According to this concept $R$-gene and its counterpart $A v r$ gene can be cloned in one gene construct which is introduced in the plant through transformation. The $R$-gene is driven by a constitutive promoter, so, $R$-gene product is always available inside the cell; whereas $A v r$ gene is driven by a pathogen inducible promoter, so that it is expressed only when the pathogen causes infection in the host. Hence, in the absence of pathogen there is no Avr protein available inside the plant cell and consequently there will not be any HR. But when the pathogen attacks, Avr proteins begin to express and starts to interact with their counterpart R-protein already present in the cell and ultimately lead to HR mediated resistance response.

Some success has been achieved by using this system in tomato against the fungal pathogen Cladosporium fulvum. Resistant transgenic tomato has been produced by using resistance gene $C f 9$ and avirlence gene $A v r 9$ in combination following the two component scheme discussed above [44]. The transgenic tomato plants are resistant to several bacterial pathogens besides Cladosporium fulvum. Such a two component system against rice blast disease can be designed where both blast resistance gene and its complementary Avr gene may have been cloned. For instance, 


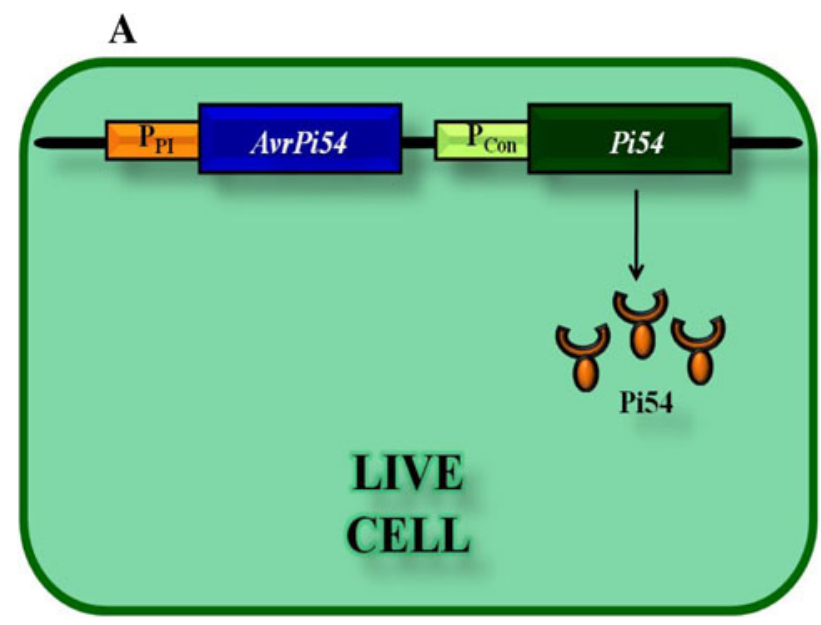

Fig. 5 Response of transformed rice cell containing $R-A v r$ two component system in the absence and presence of $M$. oryzae infection. a The Pi54 gene is driven by a constitutive promoter CaMV35S $\left(\mathrm{P}_{\mathrm{Con}}\right)$, so its protein product, $\mathrm{Pi} 54$, is always present in the cell. But in the absence of the pathogen infection, the pathogen inducible promoter $\left(\mathrm{P}_{\mathrm{PI}}\right)$ of $A v r$ gene is not activated and hence AvrPi54 gene product is not produced. As a consequence, there is no

we have cloned blast resistance gene Pi54 from rice cultivar 'Tetep'. It shows broad spectrum resistance against several isolates prevalent in India [100]. We are also in the process of cloning of its counterpart avirulence gene, AvrPi54, from M. oryzae isolate RML-29 which is avirulent on Pi54 containing genotypes and the pathogen inducible promoter from rice plant itself which is responsive to a broad range of $M$. oryzae isolates and carry out early induction of downstream genes (unpublished findings). Once the AvrPi54 gene and pathogen responsive promoter is cloned and characterized, we will be using them along with $P i 54$ gene itself and constitutive promoter CaMV35S to constitute $R$ - $A v r$ two component system capable of imparting broad spectrum resistance against $M$. oryzae. The construct will be designed by hooking the Pi54 gene downstream to CaMV35S promoter while the $A v$ rPi54 gene downstream to pathogen responsive promoter and will be used to transform susceptible rice line (Fig. 5). So, in absence of the pathogen Pi54 gene will be expressed but not the AvrPi54 and hence, there will be no cell death (Fig. 5a). But during the infection of M. oryzae the pathogen responsive promoter will get activated and it will drive the expression of AvrPi54 gene. Under this circumstance, where both Pi54 and AvrPi54 proteins are present inside the cell, their interaction will lead to hypersensitive cell death, stopping further spread of the pathogen (Fig. 5b). This strategy would provide broad-spectrum resistance to different isolates of $M$. royzae.

Acknowledgments T R Sharma is thankful to the NAIP-ICAR for financial assistance for cloning and characterization of avirulence gene and pathogen responsive promoters. He is also thankful to the

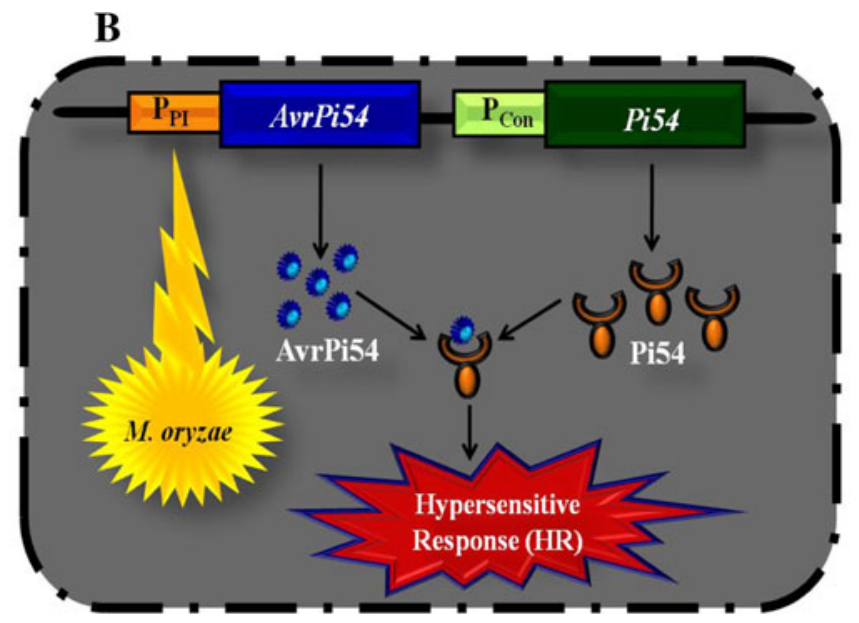

hypersensitive response $(H R)$ and cell remains alive (green cell with intact cell membrane). b In contrast, during pathogen infection the pathogen inducible promoter $\left(\mathrm{P}_{\mathrm{PI}}\right)$ of AvrPi54 gene gets activated and its protein product is produced inside the cell. This leads to interaction between Pi54 and AvrPi54 proteins followed by HR and as a consequence the infected cell dies (black cell with degenerated cell membrane) stopping the further spread of the pathogen

DBT for providing funding for the cloning of Pi54 (Pi-kh) blast resistance gene from rice.

\section{References}

1. Ahn SN, Kim YK, Hong HC, Han SS, Kwon SJ, Choi HC, Moon HP, McCouch SR (1996) Molecular mapping of a gene for resistance to a Korean isolate of rice blast. Rice Genet Newsl 13:74

2. Amante-Bordeos A, Sitch LA, Nelson R, Damacio RD, Oliva NP, Aswidinnoor H, Leung H (1992) Transfer of bacterial blight and blast resistance from the tetraploid wild rice Oryza minuta to cultivated rice. Oryza sativa. Theor Appl Genet 84:345-354

3. Ashikawa I, Hayashi N, Yamane H, Kanamori H, Wu J (2008) Two adjacent nucleotide-binding site-leucine-rich repeat class genes are required to confer pikm-specific rice blast resistance. Genetics 180:2267-2276

4. Ballini E, Morel J-B, Droc G, Price A, Courtois B, Notteghem J-L, Tharreaul D (2008) A genome-wide meta-analysis of rice blast resistance genes and quantitative trait loci provides new insights into partial and complete resistance. Mol Plant Microbe Interact 21:859-868

5. Barman SR, Chattoo BB (2004) Identification of a major blast resistance gene in the rice cultivar Tetep. Plant Breed 123:300302

6. Bohnert HU, Fudal I, Dioh W, Tharreau D, Notteghem JL, Lebrun MH (2004) A putative polyketide synthase/peptide synthetase from Magnaporthe grisea signals pathogen attack to resistant rice. Plant Cell 16:499-513

7. Bryan GT, Wu K-S, Farrall L, Jia Y, Hershey HP, McAdams SA, Faulk KN, Donaldson GK, Tarchini R, Valent B (2000) A single amino acid difference distinguishes resistant and susceptible alleles of the rice blast resistance gene Pi-ta. Plant Cell 12:2033-2046

8. Cai M, Qiu D, Yuan T, Ding X, Li H, Duan L, Xu C, Li X, Wang S (2008) Identification of novel pathogen-responsive ciselements and their binding proteins in the promoter of 
OsWRKY13, a gene regulating rice disease resistance. Plant Cell Environ 31:86-96

9. Causse MA, Fulton TM, Cho YG, Ahn SN, Chunwongse J, Wu K, Xiao J, Yu ZH, Ronald PC, Harrington SE, Second G, McCouch SR, Tanksley SD (1994) Saturated molecular map of the rice genome based on an interspecific backcross population. Genetics 138:1251-1274

10. Chauhan RS, Farman ML, Zhang HB, Leong SA (2002) Genetic and physical mapping of a rice blast resistance locus, PiCO39(t), that corresponds to the avirulence gene AVR1-CO39 of Magnaporthe grisea. Mol Gen Genomics 267:603-612

11. Chen DH, Dela Vina M, Inukai T, Mackill DJ, Ronald PC, Nelson RJ (1999) Molecular mapping of the blast-resistance gene, Pi44(t), in a line derived from a durably resistant rice cultivar. Theor Appl Genet 98:1046-1053

12. Chen S, Wang L, Que Z, Pan R, Pan Q (2005) Genetic and physical mapping of $P i 37(t)$, a new gene conferring resistance to rice blast in the famous cultivar St. No. 1. Theor Appl Genet 111:1563-1570

13. Chen XW, Li SG, Xu JC (2004) Identification of two blast resistance genes in a rice variety, Digu. J Phytopathol 152:77-85

14. Chen XW, Li SG, Ma YQ, Li HY, Zhou KD, Zhu LH (2004) Marker-assisted selection and pyramiding for three blast resistance genes, $P i-d(t) 1, P i-b, P i-t a 2$, in rice. Sheng Wu Gong Cheng Xue Bao 20:708-714

15. Chen XW, Shang J, Chen D, Lei C, Zou Y, Zhai W, Liu G, Xu J, Ling Z, Cao G, Ma B, Wang Y, Zhao X, Li S, Zhu L (2006) A $\mathrm{B}$-lectin receptor kinase gene conferring rice blast resistance. Plant J 46:794-804

16. Comai L, Young K, Till BJ, Reynolds SH, Greene EA, Codomo CA, Enns LC, Johnson JE (2004) Efficient discovery of DNA polymorphisms in natural populations by Ecotilling. Plant $\mathrm{J}$ 37:778-786

17. De Wit PJGM (1992) Molecular characterization of gene-forgene systems in plant-fungus interactions and the applications of avirulence genes in control of plant pathogens. Annu Rev Phytopathol 30:391-481

18. Dean RA, Talbot NJ, Ebbole DJ, Farman ML, Mitchell TK, Orbach MJ, Thon M, Kulkarni R, Xu J-R, Pan H, Read ND, Lee Y-H, Carbone I, Brown D, Oh YY, Donofrio N, Jeong JS, Soanes DM, Djonovic S, Kolomiets E, Rehmeyer C, Li W, Harding M, Kim S, Lebrun M-H, Bohnert H, Coughlan S, Butler J, Calvo S, Ma L-J, Nicol R, Purcell S, Nusbaum C, Galagan JE, Birren BW (2005) The genome sequence of the rice blast fungus Magnaporthe grisea. Nature 434:980-986

19. Deng Y, Zhu X, Shen Y, He Z (2006) Genetic characterization and fine mapping of the blast resistance locus Pigm(t) tightly linked to Pi2 and Pi9 in a broad-spectrum resistant Chinese variety. Theor Appl Genet 113:705-713

20. Dwinita WU, Sugiono M, Hajrial A, Asep S, Ida H (2008) Blast resistance genes in wild rice Oryza rufipogon and rice cultivar IR64. Ind J Agric 1:71-76

21. Evrard A, Meynard D, Guiderdoni E (2007) The promoter of the wheat puroindoline-a gene (PinA) exhibits a more complex pattern of activity than that of the PinB gene and is induced by wounding and pathogen attack on rice. Planta 225:287-300

22. Farman ML, Leong SA (1998) Chromosome walking to the AVR1-CO39 avirulence gene of Magnaporthe grisea: discrepancy between the physical and genetic maps. Genetics 150: 1049-1058

23. Fjellstrom RG, Conaway-Bormans CA, McClung AM, Marchetti MA, Shank AR, Park WD (2004) Development of DNA markers suitable for marker assisted selection of three Pi genes conferring resistance to multiple Pyricularia grisea pathotypes. Crop Sci 44:1790-1798
24. Flor HH (1955) Host-parasite interaction in flax rust-its genetics and other implications. Phytopathology 45:680-685

25. Fujii K, Hayano-Saito Y, Sugiura N, Hayashi N, Saka N, Tooyama T, Izawa T, Shumiya A (1999) Gene analysis of panicle blast resistance in rice cultivars with rice stripe resistance. Breed Res 1:203-210

26. Fujii K, Hayano-Saito Y, Shumiya A, Inoue M (1995) Genetical mapping based on the RFLP analysis for the panicle blast resistance derived from a rice parental line St. No. 1. Breed Sci 45:209

27. Fukuoka S, Okuno K (2001) QTL analysis and mapping of pi21, a recessive gene for field resistance to rice blast in Japanese upland rice. Theor Appl Genet 103:185-190

28. Geng XS, Yang MZ, Huang XQ, Cheng ZQ, Fu J, Sun T, Li J (2008) Cloning and analyzing of rice blast resistance gene $P i$ $t a+$ allele from Jinghong erect type of common wild rice (Oryza rufipogon Griff) in Yunnan. Yi Chuan 30(1):109-114

29. Goldsbrough A, Albrecht H, Stratford R (1993) Salicylic acidinducible binding of a tobacco nuclear protein to a $10 \mathrm{bp}$ sequence which is highly conserved amongst stress-inducible genes. Plant J 3:563-571

30. Goto I (1970) Genetic studies on the resistance of rice plant to the blast fungus I. Inheritance of resistance in crosses Sensho $x$ H-79 and Imochishirazu x H-79. Ann Phytopathol Soc Jap 36:304-312

31. Goto I (1976) Genetic studies on resistance of rice plant to blast fungus II. Difference in resistance to the blast disease between Fukunishiki and its parental cultivar, Zenith. Ann Phytopathol Soc Jap 42:253-260

32. Goto I (1988) Genetic studies on resistance of rice plant to blast fungus (VII). Blast resistance genes of Kuroka. Ann Phytopathol Soc Jap 54:460-465

33. Goto I, Jaw YL, Baluch AA (1981) Genetic studies on resistance of rice plant to blast fungus IV. Linkage analysis of four genes, Pi-a, Pi-k, Pi-z and Pi-i. Ann Phytopathol Soc Jap 47:252-254

34. Gowda M, Roy-Barman S, Chattoo BB (2006) Molecular mapping of a novel blast resistance gene Pi38 in rice using SSLP and AFLP markers. Plant Breed 125:596-599

35. Gupta SK, Rai AK, Kanwar SS, Chand D, Singh NK, Sharma TR (2011) The single functional blast resistance gene Pi54 activates a complex defense mechanism in rice. J Exp Bot. doi: $10.1093 / \mathrm{jxb} / \mathrm{err} 297$

36. Hammond-Kosack KE, Jones JDG (1997) Plant disease resistance genes. Ann Rev Plant Physiol Plant Mol Biol 48:575-607

37. Hayasaka H, Miyao A, Yano M, Matsunaga K, Sasaki T (1996) RFLP mapping of a rice blast resistance gene Pi-k. Breed Sci 46(Suppl. 2):68

38. Hayashi K, Yasuda N, Fujita Y, Koizumi S, Yoshida H (2010) Identification of the blast resistance gene Pit in rice cultivars using functional markers. Theor Appl Genet 121(7):1357-1367

39. Hayashi K, Yoshida H, Ashikawa I (2006) Development of PCR-based allele specific and InDel marker sets for nine rice blast resistance genes. Theor Appl Genet 113:251-260

40. Hayashi N, Inoue H, Kato T, Funao T, Shirota M, Shimizu T, Kanamori H, Yamane H, Hayano-Saito Y, Matsumoto T, Yano M, Takatsuji H (2010) Durable panicle blast-resistance gene $\mathrm{Pb} 1$ encodes an atypical CC-NBS-LRR protein and was generated by acquiring a promoter through local genome duplication. Plant J 64:498-510

41. Hayashi N, Ando I, Naito H (1996) Gene analysis of a new blast resistance in the paddy rice variety, Aichi Asahi. Breed Sci 46(Suppl. 2): 168

42. He Y, Li X, Zhang J, Jiang G, Liu S, Chen S, Tu J, Xu C, Zhang $\mathrm{Q}$ (2004) Gene pyramiding to improve hybrid rice by molecular marker techniques. $4^{\text {th }}$ International Crop Science Congress, Brisbane. Queensland, Australia 
43. Hittalmani S, Parco A, Mew TV, Zeigler RS, Huang N (2000) Fine mapping and DNA marker-assisted pyramiding of the three major genes for blast resistance in rice. Theor Appl Genet 100:1121-1128

44. Honee G, Melchers LS, Vleeshouwers VGAA, Van RJSC, De Wit PJGM (1995) Production of the AVR9 elicitor from the fungal pathogen Cladosporium fulvum in transgenic tobacco and tomato plants. Plant Mol Biol 29:909-920

45. Hong JK, Hwang BK (2006) Promoter activation of pepper class II basic chitinase gene, CAChi2, and enhanced bacterial disease resistance and osmotic stress tolerance in the CAChi2-overexpressing Arabidopsis. Planta 223:433-448

46. Hong JK, Lee SC, Hwang BK (2005) Activation of pepper basic $P R-1$ gene promoter during defense signaling to pathogen, abiotic and environmental stresses. Gene 356:169-180

47. Huang C-L, Hwang S-Y, Chiang Y-C, Lin T-P (2008) Molecular evolution of the $P i$-ta gene resistant to rice blast in wild rice (Oryza rufipogon). Genetics 179:1527-1538

48. Huang H, Huang L, Feng G, Wang S, Wang Y, Liu J, Jiang N, Yan W, Xu L, Sun P, Li Z, Pan S, Liu X, Xiao Y, Liu E, Dai L, Wang GL (2011) Molecular mapping of the new blast resistance genes Pi47 and Pi48 in the durably resistant local rice cultivar Xiangzi 3150. Phytopathology 101(5):620-626

49. Hwang SH, Lee IA, Yie SW, Hwang DJ (2008) Identification of an OSPR10a promoter region responsive to salicylic acid. Planta 227:1141-1150

50. Imbe T, Matsumoto S (1985) Inheritance of resistance of rice varieties to the blast fungus strains virulent to the variety "Reiho". Jap J Breed 35:332-339

51. Imbe T, Oba S, Yanoria MJT, Tsunematsu H (1997) A new gene for blast resistance in rice cultivar, IR24. Rice Genet Newsl 14:60-62

52. Inukai T, Nelson RJ, Zeigler RS, Sarkarung S, Mackill DJ, Bonman JM, Takamure I, Kinoshita T (1996) Genetic analysis of blast resistance in tropical rice cultivars using near-isogenic lines. In: Khush GS (ed) Rice genetics III, Proceeding of the third international rice genetics symposium, International Rice Research Institute, Manila, Philippines, pp 447-455

53. Ise K (1991) Linkage analysis of some blast resistance gene in rice, Oryza sativa L. Jap J Breed 42(Suppl. 2):388-389

54. Iwata N (1996) Registration of new gene symbols. Rice Genet Newsl 13:12-18

55. Jeon JS, Chen D, Yi GH, Wang GL, Ronald PC (2003) Genetic and physical mapping of Pi5(t), a locus associated with broadspectrum resistance to rice blast. Mol Gen Genomics 269:280289

56. Jeung JU, Kim BR, Cho YC, Han SS, Moon HP, Lee YT, Jena KK (2007) A novel gene, Pi40 (t), linked to the DNA markers derived from NBS-LRR motifs confers broad spectrum of blast resistance in rice. Theor Appl Genet 115:1163-1177

57. Jones DJ, Dangl JL (2006) The plant immune system. Nature 444:323-328

58. Joshi BK, Bimb HP, Parajuli G, Chaudhary B (2009) Molecular tagging, allele mining and marker aided breeding for blast resistance in rice. BSN e-Bulletin Vol. 1

59. Jung HW, Kim KD, Hwang BK (2005) Identification of pathogenresponsive regions in the promoter of a pepper lipid transfer protein gene (CALTPI) and the enhanced resistance of the $C A L$ TPI transgenic Arabidopsis against pathogen and environmental stresses. Planta 221:361-373

60. Kaji R, Ogawa T (1996) RFLP mapping of a blast resistance gene, $P i-k m$, in rice. Breed Sci 46(Suppl. 2):70

61. Kang S, Sweigard JA, Valent B (1995) The $P W L$ host specificity gene family in the blast fungus Magnaporthe grisea. Mol Plant Microbe Interact 8:939-948
62. Khush GS, Jena KK (2009) Current status and future prospects for research on blast resistance in rice (Oryza sativa L.). In: Wang G-L, Valent B (eds) Advances in genetics, genomics and control of rice blast disease. doi:10.1007/978-1-4020-9500-9

63. Khush GS (1997) Origin, dispersal, cultivation and variation of rice. Plant Mol Biol 35:25-34

64. Kinoshita T, Kiyosawa S (1997) Some considerations on linkage relationships between Pii and Piz in the blast resistance of rice. Rice Genetics Newsl 14:57-59

65. Kiyosawa S, Ando I (1990) Blast resistance. In: Matzo T (ed) Science of rice plant, vol. 3 genetics. Nosan-Gyoson Bunka Kyokai, Tokyo, pp 361-385

66. Kiyosawa S (1967) Genetic studies on host-pathogen relationship in the rice blast disease. Proc. Symp. Rice diseases and their control by growing resistant varieties and other measures. Tokyo, p. 137-153

67. Koide Y, Kawasaki A, Telebanco-Yanorial MJ, Hairmansis A, Nguyet NTM, Bigirimana J, Fujita D, Kobayashi N, Fukuta Y (2010) Development of pyramided lines with two resistance genes, Pish and Pib, for blast disease (Magnaporthe oryzae B. Couch) in rice (Oryza sativa L.). Plant Breeding 129:670-675

68. Kumar P, Pathania S, Katoch P, Sharma TR, Plaha P, Rathour R (2010) Genetic and physical mapping of blast resistance gene $P i-42(t)$ on the short arm of rice chromosome 12. Mol Breed 25:217-228

69. Kumar SP, Dalal V, Singh NK, Sharma TR (2007) Comparative analysis of the $100 \mathrm{~kb}$ region containing the $P i-k(h)$ locus between indica and japonica rice lines. Genomics Proteomics Bioinformatics 5:35-44

70. Lee SK, Song MY, Seo YS, Kim HK, Ko S (2009) Rice Pi5mediated resistance to Magnaporthe oryzae requires the presence of two CC-NB-LRR Genes. Genetics 181:1627-1638

71. Lei CL, Huang DY, Lil WJ, Wang L, Liu ZL, Wang XT, Shi K, Cheng ZJ, Zhang X, Ling ZZ, Wan JM (2005) Molecular mapping of a blast resistance gene in an indica rice cultivar Yanxian No. 1. Rice Genet Newsl 22:76-77

72. Li W, Wang B, Wu J, Lu G, Hu Y, Zhang X, Zhang Z, Zhao Q, Feng Q, Zhang H, Wang Z, Wang G, Han B, Wang Z, Zhou B (2009) The Magnaporthe oryzae avirulence gene AvrPiz-t encodes a predicted secreted protein that triggers the immunity in rice mediated by the blast resistance gene Piz-t. Mol Plant Microbe Interact 22:411-420

73. Lin F, Chen S, Que Z, Wang L, Liu X (2007) The blast resistance gene Pi37 encodes an NBS-LRR protein and is a member of a resistance gene cluster on rice chromosome 1. Genetics 177:1871-1880

74. Liu B, Zhang S, Zhu X, Yang Q, Wu S, Mei M, Mauleon R, Leach J, Mew T, Leung H (2004) Candidate defense genes as predictors of quantitative blast resistance in rice. Mol Plant Microbe Interact 17:1146-1152

75. Liu S-P, Li X, Wang C, Li X-H, He Y-Q (2003) Improvement of resistance to rice blast in Zhenshan 97 by molecular markeraided selection. Acta Bot Sinica 45:1346-1350

76. Liu XQ, Wang L, Chen S, Lin F, Pan QH (2005) Genetic and physical mapping of Pi36(t), a novel rice blast resistance gene located on rice chromosome 8. Mol Gen Genomics 274:394-401

77. Liu X, Yang Q, Lin F, Hua L, Wang C, Wang L, Pan Q (2007) Identification and fine mapping of Pi39(t), a major gene conferring the broad-spectrum resistance to Magnaporthe oryzae. Mol Gen Genomics 278:403-410

78. Mackill DJ, Bonman JM (1992) Inheritance of blast resistance in near-isogenic lines of rice. Phytopathology 82:746-749

79. McCouch SR, Nelson RJ, Tohme J, Zeigler RS (1994) Mapping of blast resistance genes in rice. In: Zeigler RS, Leong SA, Teng PS (eds) Rice blast disease. C.A.B. International, Wallingford UK, pp 167-186 
80. Michelmore RW, Meyers BC (1998) Clusters of resistance genes in plants evolve by divergent selection and a birth-anddeath process. Genome Res 8:1113-1130

81. Molina J, Sikorab M, Garudb N, Flowersa JM, Rubinsteina S, Reynoldsb A, Huangc P, Jacksond S, Schaalc BA, Bustamanteb CD, Boykob AR, Purugganana MD (2011) Molecular evidence for a single evolutionary origin of domesticated rice. Proc Nat Acad Sci 108:10-15

82. Nakamura S, Asakawa S, Ohmido N, Fukui K, Shimizu N, Kawasaki S (1997) Construction of an 800-kb contig in the nearcentromeric region of the rice blast resistance gene Pi-ta2 using a highly representive rice BAC library. Mol Gen Genomics 254:611-620

83. Naqvi NI, Chattoo BB (1996) Development of a sequence characterized amplified region (SCAR) based indirect selection method for a dominant blast-resistance gene in rice. Genome 39:26-30

84. Narayanan NN, Baisakh N, Vera Cruz CM, Gnanamanickam SS, Datta K, Datta SK (2002) Molecular breeding for the development of blast and bacterial blight resistance in rice cv. IR50. Crop Sci 42:2072-2079

85. Narayanan NN, Niranjan B, Norman PO, Casiana MV, Samuel SG, Karabi D, Datta SK (2004) Molecular breeding: markerassisted selection combined with biolistic transformation for blast and bacterial blight resistance in Indica rice (cv. CO39). Mol Breeding 14:61-71

86. Nguyen TTT, Koizumi S, La TN, Zenbayashi KS, Ashizawa T, Yasuda N, Imazaki I, Miyasaka A (2006) Pi35(t), a new gene conferring partial resistance to leaf blast in the rice cultivar Hokkai 188. Theor Appl Genet 113:697-704

87. Okuyama Y, Kanzaki H, Abe A, Yoshida K, Tamiru M, Saitoh H, Fujibe T, Matsumura H, Shenton M, Galam DC, Undan J, Ito A, Sone T, Terauchi R (2011) A multifaceted genomics approach allows the isolation of the rice Pia blast resistance gene consisting of two adjacent NBS-LRR protein genes. Plant $\mathbf{J}$ 66:467-479

88. Oldroyd GED, Staskawicz BJ (1998) Genetically engineered broad-spectrum disease resistance in tomato. Proc Nat Acad Sci 95:10300-10305

89. Orbach MJ, Farrall L, Sweigard JA, Chumley FG, Valent B (2000) A telomeric avirulence gene determines efficacy for the rice blast resistance gene $P i$-ta. Plant Cell 12:2019-2032

90. Padmanabhan SY (1965) Breeding for blast resistance in India. Proc Indian Acad Sci 49:349-362

91. Pan HQ, Tanisaka T, Ikehashi H (1996) Studies on the genetics and breeding of blast resistance in rice VI. Gene analysis of the blast resistance of two Yunnan native cultivars GA20 and GA25. Breed Sci 46(Suppl 2):70

92. Pan QH, Hu ZD, Tanisaka T, Wang L (2003) Fine mapping of the blast resistance gene Pi15, linked to Pii, on rice chromosome 9. Acta Bot Sinica 45:871-877

93. Pan QH, Tanisaka T, Ikehashi H (1995) Studies on the genetics and breeding of blast resistance in rice IV Gene analysis for the blast resistance of a indica variety Kasalath. Breed Sci 45(Suppl. 2): 170

94. Pan QH, Wang L, Tanisaka T (1999) A new blast resistance gene identified in the Indian native rice cultivar Aus 373 through allelism and linkage tests. Plant Pathol 48:288-293

95. Pan QH, Wang L, Ikehashi H, Tanisaka T (1996) Identification of a new blast resistance gene in the indica rice cultivar Kasalath using Japanese differential cultivars and isozyme markers. Phytopathology 86:1071-1075

96. Pan QH, Wang L, Ikehashi H, Yamagata H, Tanisaka T (1998) Identification of two new genes conferring resistance to rice blast in the Chinese native cultivar 'Maowangu'. Plant Breed. 117:27-31
97. Park HC, Kim ML, Kang YH, Jeong JC, Cheong MS, Choi W, Lee SY, Cho MJ, Kim MC, Chung WS, Yun D-J (2009) Functional analysis of the stress-inducible soybean calmodulin isoform-4 $(\mathrm{GmCaM}-4)$ promoter in transgenic tobacco plants. Mol Cells 27:475-480

98. Parker D, Beckmann M, Enot DP, Overy DP, Rios ZC, Gilbert M, Talbot N, Draper J (2008) Rice blast infection of Brachypodium distachyon as a model system to study dynamic host/ pathogen interactions. Nat Protoc 3:435-445

99. Qu S, Liu G, Zhou B, Bellizzi M, Zeng L, Dai L, Han B, Wang $\mathrm{G}$ (2006) The broad-spectrum blast resistance gene $P i 9$ encodes an NBS-LRR protein and is a member of a multigene family in rice. Genetics 172:1901-1914

100. Rai AK, Kumar SP, Gupta SK, Gautam N, Singh NK, Sharma TR (2011) Functional complementation of rice blast resistance gene $\mathrm{Pi}-\mathrm{k}^{h}$ (Pi54) conferring resistance to diverse strains of Magnaporthe oryzae. J Plant Biochem Biotechnol 20:55-65

101. Rai AN, Das A, Gupta YK, Thakur S, Singh PK, Upreti HC, Singh NK, Sharma TR (2011a) Allele mining of rice blast resistance gene Pi54 from wild and cultivated species of rice. Cereal Res Commun (in press)

102. Ram T, Majumder ND, Mishra B, Ansari MM, Padmavathi G (2007) Introgression of broad-spectrum blast resistance gene(s) into cultivated rice (Oryza sativa ssp indica) from wild rice $O$. rufipogon. Curr Sci 92:225-230

103. Rathour R, Gaur VS, Kaushik RP, Chauhan RS (2005) Oryza rufipogon A possible source of novel resistance specificities against rice blast (Magnaporthe grisea). Curr Sci 89:1-4

104. Rice Chromosomes 11, 12 Sequencing Consortia (2005) The sequence of rice chromosomes 11 and 12 , rich in disease resistance genes and recent gene duplications. BMC Biol 3:20

105. Rushton PJ, Somssich IE (1998) Transcriptional control of plant genes responsive to pathogens. Curr Opin Plant Biol $1: 311-315$

106. Rushton PJ, Reinstadler A, Lipka V, Lippok B, Somssich IE (2002) Synthetic plant promoters containing defined regulatory elements provide novel insights into pathogen- and woundinduced signaling. Plant Cell 14:749-762

107. Sallaud C, Lorieux M, Roumen E, Tharreau D, Berruyer R, Svestasrani P, Garsmeur O, Ghesquiere A, Notteghem JL (2003) Identification of five new blast resistance genes in the highly blast-resistant rice variety IR64 using a QTL mapping strategy. Theor Appl Genet 106:794-803

108. Shang J, Tao Y, Chen X, Zou Y, Lei C, Wang J, Li X, Zhao X, Zhang M, Lu Z, Xu J, Cheng Z, Wan J, Zhu L (2009) Identification of a new rice blast Resistance gene, Pid3, by genome wide comparison of paired nucleotide-binding site-leucine-rich repeat genes and their pseudogene alleles between the two sequenced rice genomes. Genetics 182:1303-1311

109. Sharma TR, Chauhan RS, Singh BM, Paul R, Sagar V, Rathore R (2002) RAPD and pathotype analysis of Magnaporthe grisea population from North-western Himalayan region of India. J Phytopathol 150:649-656

110. Sharma TR, Gupta YK, Thakur S, Singh PK, Upreti HC, Singh NK, Singh UD, Rathour R, Kapoor AS, Kaushik RP, Variar M, Maiti D, Mandal NP, Prashanti SK, Hanamaratti NG (2009) Allele mining for important blast resistance genes from Indian land races of rice. $6^{\text {th }}$ International Rice Genetics Symposium. Manila, Philipines

111. Sharma TR, Madhav MS, Singh BK, Shanker P, Jana TK, Dalal V, Pandit A, Singh A, Gaikwad K, Upreti HC, Singh NK (2005) High-resolution mapping, cloning and molecular characterization of the $P i-k^{h}$ gene of rice, which confers resistance to Magnaporthe grisea. Mol Gen Genomics 274:569-578 
112. Sharma TR, Rai AK, Gupta SK, Singh NK (2010) Broad spectrum blast resistance gene $P i-k^{h}$ designated as Pi-54. J Plant Biochem Biotechnol 19:987-989

113. Sharma TR, Shanker P, Singh BK, Jana TK, Madhav MS, Gaikwad G, Singh NK, Plaha P, Rathour R (2005) Molecular mapping of rice blast resistance gene $P i-k^{h}$ in rice variety Tetep. J Plant Biochem Biotechnol 14:127-133

114. Shinoda H, Toriyama K, Yunoki T, Ezuka A, Sakurai Y (1971) Studies on the varietal resistance of rice to blast. VI. Linkage relationship of blast resistance genes. Bull Chugoku Nat Agric Exp Stat A 20:1-25

115. Singh AK, Gopalakrishnan S, Singh VP, Prabhu KV, Mohapatra T, Singh NK, Sharma TR, Nagarajan M, Vinod KK, Singh Devinder, Singh UD, Chander Subhash, Atwal SS, Seth Rakesh, Singh VK, Ranjith KE, Singh A, Deepti A, Apurva K, Sheel Y, Nitika G, Singh A, Shikari AB, Singh A, Marathi B (2011) Marker assisted selection: a paradigm shift in Basmati breeding. Indian J Genet 71:1-9

116. Sitch LA, Amante AD, Dalmacio RD, Leung H (1989) Oryza minuta, a source of blast and bacterial blight resistance for rice improvement. In: Mujeeb-Kazi A, Sitch LA (eds) Review of advances in plant biotechnology. CIMMYT, Mexico and IRRI, pp 315-322

117. Sweigard JA, Carroll AM, Kang S, Farrall L, Chumley FG, Valent B (1995) Identification, cloning, and characterization of $P W L 2$, a gene for host species specificity in the rice blast fungus. Plant Cell 7:1221-1233

118. Tabien RE, Li Z, Paterson AH, Marchetti MA, Stansel JW, Pinson SRM (2000) Mapping of four rice blast resistance genes from 'Lemont' and 'Teqing' and evaluation of their combinatorial effect for field resistance. Theor Appl Genet 101:12151225

119. Tabien RE, Pinson SRM, Marchetti MA, Li Z, Park WD, Paterson AH, Stansel JW (1996) Blast resistance genes from Teqing and Lemont. In: Khush GS (ed) Rice genetics III. Proceedings of Third International Rice Genetics Symposium, Oct 16-20. Manila, The Philippines, pp 451-455

120. Takken FL, Tameling WI (2009) To nibble at plant resistance proteins. Science 324:744-746

121. Tian D, Traw MB, Chen JQ, Kreitman M, Bergelson J (2003) Fitness costs of R-gene-mediated resistance in Arabidopsis thaliana. Nature 423:74-77

122. Till BJ, Reynolds SH, Green EA, Codomo CA, Enns LC, Johnson JE (2003) Large-scale discovery of induced point mutations with high-throughput TILLING. Genome Res 13:524-530

123. Wang GL, Mackill DJ, Bonman JM, McCouch SR, Champoux MC, Nelson RJ (1994) RFLP mapping of genes conferring complete and partial resistance to blast in a durably resistant rice cultivar. Genetics 136:1421-1434

124. Wang L, Xu XK, Lin F, Pan QH (2009) Characterization of rice blast resistance genes in the Pik cluster and fine mapping of the Pik- $p$ locus. Phytopathology 99:900-905

125. Wang Z-X, Yano M, Yamanouchi U, Iwamoto M, Monna L, Hayasaka H, Katayose Y, Sasaki Takuji (1999) The Pib gene for rice blast resistance belongs to the nucleotide binding and leucine-rich repeat class of plant disease resistance genes. Plant $\mathrm{J}$ 19:55-64

126. Wu JL, Fan YY, Li DB, Zheng KL, Leung H, Zhuang JY (2005) Genetic control of rice blast resistance in the durably resistant cultivar Gumei 2 against multiple isolates. Theor Appl Genet 111:50-56

127. Wu KS, Martinez C, Lentini Z, Tohme J, Chumley FG, Scolnik PA, Valent B (1996) Cloning a blast resistance gene by chromosome walking. In: Khush GS (ed) Rice genetics III. Proceeding of the third international rice genetics symposium, International Rice Research Institute, Manila, Philippines, pp 669-674

128. Yang MZ, Cheng ZQ, Chen SN, Qian J, Xu LL, Huang XQ (2007) A rice blast-resistance genetic resource from wild rice in Yunnan, China. Zhi Wu Sheng Li Yu Fen Zi Sheng Wu Xue Xue Bao 33:589-595

129. Yang Q, Lin F, Wang L, Pan Q (2009) Identification and mapping of Pi41, a major gene conferring resistance to rice blast in the Oryza sativa subsp. indica reference cultivar, 93-11. Theor Appl Genet 118:1027-1034

130. Yokoo M, Kikuchu F, Fujimaki H, Nagai K (1978) Breeding of blast resistance lines (BL1 to 7) from indica-japonica crosses of rice. Jap J Breed 28:359-385

131. Yoshida K, Saitoh H, Fujisawa S, Kanzaki H, Matsumura H, Yoshida K, Tosa y, Chuma I, Takano Y, Win J, Kamoun S, Terauchia R (2009) Association genetics reveals three novel avirulence genes from the rice blast fungal pathogen Magnaporthe oryzae. Plant Cell 21:1573-1591

132. Young BJD, Innes RW (2006) Plant NBS-LRR proteins in pathogen sensing and host defense. Nature Immunol 7:12431249

133. Yu ZH, Mackill DJ, Bonman JM, Tanksley SD (1991) Tagging genes for blast resistance in rice via linkage to RFLP markers. Theor Appl Genet 81:471-476

134. Zeigler RS, Couc LX, Scott RP, Bernardo MA, Chen DH, Valent B, Nelson R (1995) The relationship between lineage and virulence in Pyricularia grisea in the Philippines. Phytopathology $85: 443-451$

135. Zenbayashi-Sawata K, Fukuoka S, Katagiri S, Fujisawa M, Matsumoto T, Ashizawa T, Koizumi S (2002) Mapping of the QTL (quantitative trait locus) conferring partial resistance to leaf blast in rice cultivar Chubu 32. Theor Appl Genet 104:547552

136. Zhai C, Lin F, Dong Z, He X, Yuan B, Zeng X, Wang L, Pan Q (2011) The isolation and characterization of $P i k$, a rice blast resistance gene which emerged after rice domestication. New Phytol 189:321-334

137. Zheng KL, Zhuang JY, Lu J, Qian HR, Lin HX (1996) Identification of DNA markers tightly linked to blast resistance genes in rice. In: Khush GS (ed) Rice genetics III. Proceeding of the third international rice genetics symposium, International Rice Research Institute, Manila, Philippines, pp 565-569

138. Zhou B, Qu S, Liu G, Dolan M, Sakai H (2006) The eight amino-acid differences within three leucine-rich repeats between Pi2 and Piz-t resistance proteins determine the resistance specificity to Magnaporthe grisea. Mol Plant Microbe Interact 19:1216-1228

139. Zhou JH, Wang JL, Xu JC, Lei CL, Ling ZZ (2004) Identification and mapping of a rice blast resistance gene Pi-g(t) in the cultivar Guangchangzhan. Plant Pathol 53:191-196

140. Zhu Q, Dabi T, Beeche A, Yamamoto R, Lawton MA, Lamb C (1995) Cloning and properties of a rice gene encoding phenylalanine ammonia-lyase. Plant Mol Biol 29:535-550

141. Zhuang JY, Wu JL, Fan YY, Rao ZM, Zheng KL (2001) Genetic drag between a blast resistance gene and QTL conditioning yield trait detected in a recombinant inbred line population in rice. Rice Genetics Newsl 18:69-70

142. Ahn S-N, Kim Y-K, Hong H-C, Han S-S, Kwon S-J, Choi H-C, Moon H-P, McCouch S (2000) Molecular mapping of a new gene for resistance to rice blast. Euphytica 116:17-22 